УДК 372: 881.111.1+ 378.937

\title{
DEVELOPING STUDENTS CRITICAL THINKING THROUGH INTRODUCING VIDEO MATERIALS INTO EDUCATIONAL PROCESS
}

\author{
T. L. Korshuk \\ Kyiv, National Technical University of Ukraine \\ "Kyiv Polytechnic Institute" \\ korshuk.tetiana@gmail.com
}

The article deals with the problem of teaching critical thinking in course of English learning. Critical thinking is one of the main principles of successful professional work. The educational process in Ukraine having long been marred by routine procedures, outdated information and old methods now undergoes a series of changes moving to European standards of Bologna process. The research of using video materials in educational process has already been studied by many scientists and philologists. The advantages of English teaching with the help of visibility, including audio, text and pictures, are proven and widely asserted by many teachers. Therefore, the video materials produce both practical and theoretical information; moreover, they provide additional motivation and can be used for interdisciplinary connections. The research shows that students taking regular tasks based on video materials are progressing faster and develop not only language skills of audition and speaking but also critical thinking skills. The tasks for developing critical thinking can be connected with teaching academic writing and speaking, namely, producing presentations and discussions. There is much to be done for developing a system or special storage of video materials that can give benefits to development students' critical thinking and therefore productivity of educational process.

Key words: critical thinking, creative methods, video materials, processing information, language competency.

Introduction. The educational process that takes place in nowadays higher institutions of Ukraine goes through a series of essential and drastic changes. The focus is more and more fixed on what personality should the educational establishment produce instead of previous idea of bringing up the specialist in one specific field. The Ukrainian educational system still has a lot of outdated laws and regulations that interfere with modern vector of youth studying, therefore teachers should do their best to provide the best level of teaching despite the flaws of the system. One of the main aspects of educating a person is to teach them think critical. For such task there can be different approaches - reading and discussing literature, essay writing and role play modeling, case studying and so on. We want to focus on using video materials for this purpose. At present students cannot imagine their life without surfing internet and/or watching videos as everyday activity. So it is productive to use their habits and make them a part of studying process.

Critical thinking was firstly recognized by John Dewey, a researcher who emphasized that a curriculum focuses at building thinking skills that would be useful for the community and the entire society. Speaking about critical thinking the reference should be made to R. J. Sternberg, whose works on critical thinking are deep and all-sided. R. T. Pithers, R. Soden, P. A. Facione and others also developed different ideas connected with teaching critical thinking and advocating its importance for education, personal and professional development. All the research works made by various scientists are worth great attention but they do not cover the idea of teaching critical thinking with the help of video materials involvement. 
The previous researches of using video in education are versatile in their analyzing different age-groups, motivation and memory stimulating processes. Dr. Thomas J. Garza is one of the most passionate researchers whose ideas are very useful and easy to apply. He researched video materials mainly looking into using them in advanced foreign language learning. Such people as C. Chen, M. Lemmens, K. A. Linsenmeier and others analyzed video materials as the source for discussion and education both students and teachers by gaining professional knowledge [4].

Most Ukrainian researchers concentrate on using video materials for learning vocabulary and listening competency (I. O. Winter, A. A. Leontiev, etc.), Ukrainian (E. V. Hlushak，A. V. Honcharuk， G. G. Zhohlina， L. S. Zaznobina， L. A. Ivanov, A. Komarov, V. Pisarenko, L. Pressman, A. B. Solomonik, V. M. Taranov, A. Shadrin, V. A. Shevchenko), while foreign researchers speak about language competency in general (B. Bliss, C. Kanninhhem, D. Cotton, R. Cooper, M. Lever, S. J. Molinski, P. Moore, J. Rose, J. Sherman, S. Ellsworth, D. Evans and others) [7; 10; 11].

The use of authentic video (excerpts from TV shows, news, feature films, documentary films, animated films, advertisements and video clips) is widely analized in works and the dissertations of various educators and researchers (E. V. Hlushak, I. A. Gonchar, M. I. Dubrovin, Y. A. Komarova, S. V. Nedyelina, V. L. Prokofiev, E. V. Rusakov. The purpose of introducing these materials into the educational process lies in formation of specific knowledge, skills, foreign language communicative competence within conversational topics in the study of foreign languages.

In our article we want to focus on using specialized and non-specialized video materials in teaching critical thinking. Due to this aim it is important to fulfil the following tasks:

- look into background of critical thinking and its various aspects;

- analyze the conditions of teaching critical thinking;

- produce an analysis of video materials available for teaching critical thinking;

- give variants of applying video materials into students' learning.

Critical thinking. While the term "critical thinking" can sound somewhat too serious, it is the thing without which people cannot live. If we look into background of this mental activity there are undisputable facts that the notion and concept of critical thinking were developed long ago, in years of Socrates, Aristotle, Platoons, Heraclitus, and all the other "fathers of the thought". Nevertheless, in post USSR countries there is a problem of developing this innate ability - the problem of education is that students are taught to follow teachers' instructions blindly, to fulfill the tasks only as the process is seen by supervisors and curriculum. They are not encouraged to give critics or evaluation of something; therefore they are pushed to deal with problem on surface, notwithstanding the need to use critical thinking skills that include analyzing, processing and making rational conclusions.

The process of critical thinking should become the main focus of education, while nowadays information is easily available - even the astrophysics or artificial intelligence creating can be researched and learnt through the world web and with the access to libraries of research institutes. Being able to process information and produce conclusions and ideas is what makes a person valuable for today and especially tomorrow's successful future. 
Critical thinking is goal-directed and purposive, "thinking aimed at forming a judgment," where the thinking itself meets standards of adequacy and accuracy" [2, p. 287].

All people are prone to critical thinking, and all are capable of this process, to a greater or lesser degree, make reasonable judgments on the basis of weighted evaluation. Everyone from a young age is a scientist learning about the world, but the ability to think critically can suffer greatly from the kind of society a person is growing, and what level of superstitions and misbelieves (often they are far-fetched ideas) the society has. To think well, a person needs to control themselves and be ready to call into question fundamental goals and ideals even if they are one's parents' or something sacred. This aspect of critical thinking leads to some very important features a person should possess or develop to be able to think critically. Hereby it is necessary to give a quotation from a research paper by Lai E.R. [5, p. 10-11] "the most commonly cited critical thinking dispositions include

- open-mindedness;

- fair-mindedness;

- the propensity to seek reason;

- inquisitiveness;

- the desire to be well-informed;

- flexibility and respect for, and willingness to entertain, others' viewpoints".

Except for the above mentioned dispositions, we want to add a few more. The first one is honesty. Critical thinking does not tolerate lies and self-deception. Man should be potent of confessing to himself what he knows and what he does not know, and how much of his desire can actually influence the reality around him. No conclusions can be considered reasonable if they are based on a desired image, rather than actual. For thinking, filled with self-deception, there is a beautiful and comprehensive term wishful thinking. The "thinker" should rather seek the answer to the question "what is it?" than to describe it, "what I want it to appear," by definition, otherwise it will be nothing but dreaming.

Freedom from authority. Critical thinking does not recognize the authority. No assertion can be considered true only on the grounds that it was said by the individual with a certain status. Authority often plays on our biological features that are generally useful - among children of our wild ancestors often survived those who listened to the warnings of parents and believed them in the absence of their own experience, and this mechanism successfully transmitted to us. In the unconscious phase of growing up, we believe everything seniors say to us, and despite the fact that the power of faith weakens with age, authoritative entity can become stronger and compensates for this gap. Teachers, governors and strong people, famous people, representatives of religions, and even persuasive liars can successfully perform for us role of the "knowledgeable" authority having more knowledge and experience. But critical thinking does not tolerate authority - it requires evidence that do not depend on the personality of the person.

The other two vital things for critical thinking are motivation and creativity. Problem solving and making decisions should be activities a person feels prone to, 
eager to fulfil. Personal characteristics such as persistence and diligence play an important role in the whole process of thinking, a person being lazy and always ready to give up will never succeed in critical thinking as it is always challenging way to formulate the idea or summarize something. Without creative thinking a person can be able just to criticize and object to something, not having imagination to produce arguments and areas of disagreement. Being motivated, interested in the subject, person starts to "twirl it" from different sides, using creative thinking to produce new unknown variants and conclusions.

Teaching critical thinking. What we should mention is that teaching critical thinking should never be led under pressure or by a teacher with dominator's character. The freedom of thought is the core of such approach to learning. The student should be encouraged to tell what he thinks, but not forced to. One of the problems of modern educational system in Ukraine is that the aspect of motivation is partly missed - the curriculum usually includes themes that do not cover up-to-date issues or use outdated methods and techniques, but the students are demanded to learn such things by heart even knowing they will never use such knowledge in their professional field. As the critical thinking deals with philosophy and gnosiology it leads us to using specific tools and procedure, as in figure offered below. The stages of critical thinking process should be kept unchanged while teaching students of 1-3 years and it can be transformed or shortened for elder audience.

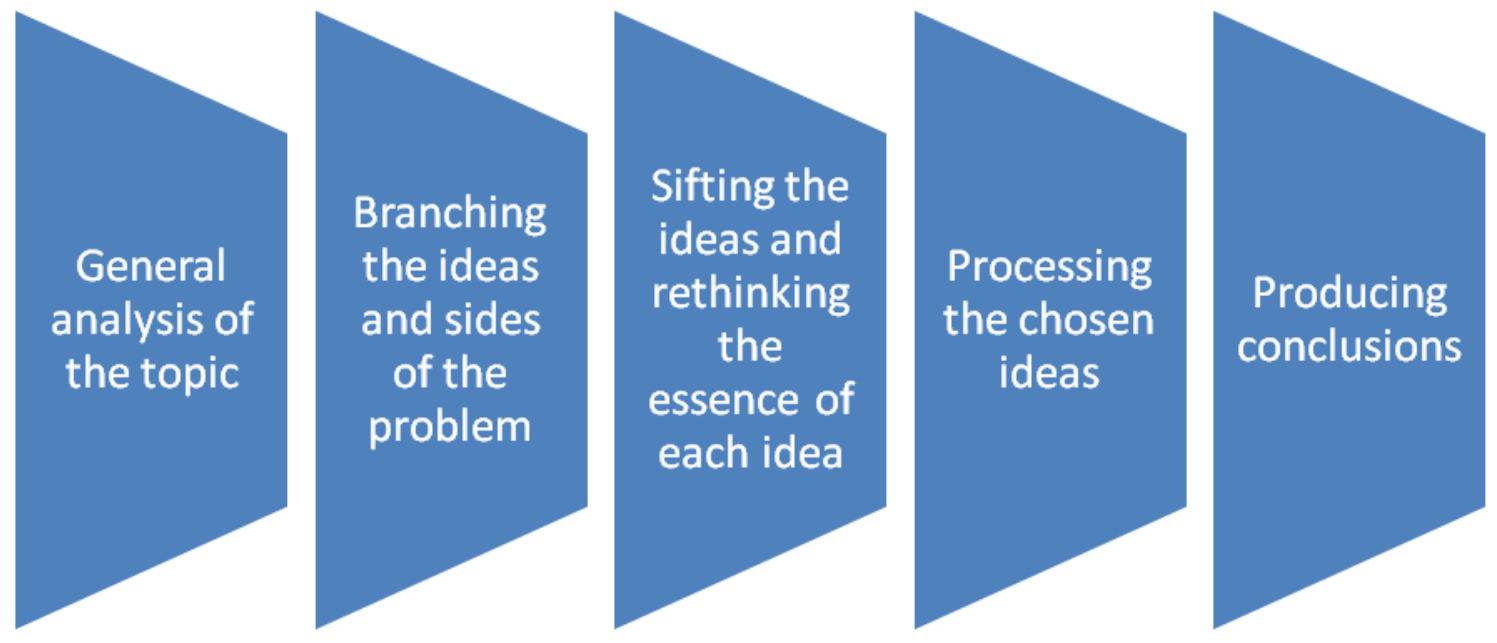

Figure 1. Critical thinking process

Video materials as an instrument for development of critical thinking. When we speak about using video in educational process, we should mention that video materials are almost perfect source for teaching, but therefore the requirement to the materials for education should be precisely met and satisfied. Video should be highly informative, with high quality picture, clear sound and logical plot. It is better if the video has subtitles and is not too long and too bright. These recommendations are applicable to all disciplines, but we should focus on teaching critical thinking while teaching English, because English, being the language study, deals with all spheres of life. While learning language people learn to be themselves - to think and communicate, deal with problems and analyze situations, make plans and be able to argue and debate on different topics. So while being taught English language students active more brain operations than while doing mathematical equations, some 
calculations of physics tasks or chemical reactions ratio etc. English language for university students includes many professional topics and themes of general knowledge.

Using video materials has a long list of advantages; visibilities, informativity, entertaining function are the most important.

The students in groups in which the topics are taught using video materials show better motivation and understanding of the topic. As this issue is of great importance there are some requirements for better productivity that can improve educational process.

The video should be short (not more than 8 minutes), preferably with subtitles. They should cover the topic or at least some element of it, be informative and suitable for introducing into lesson plan or as addition to home task from the curriculum. Different tasks should be worked out and offered for working with video. Teachers are obligated to use various educational tools and approaches, therefore students are asked to answer the questions, prepare the retelling, decide if statements are true or false, for videos without subtitles - choose the right word/phrase to put in (open cloze), write the ending or transcript for some part of the video, make a vocabulary for the video etc. But, as the aim is to develop critical thinking skills, students are also asked to write a short review on each video, to make a prediction or explain the advantages or disadvantages of something. This kind of work is not limited by the video theme and plot, because one crucial thing for developing critical thinking is diversity of topics covered, while the video material stands as trigger - the initiating factor for the thinking about some concept, process or issue. The same video can produce dozens of ideas for consideration.

Teachers should use various kinds of videos, with open-ended tasks and realworld problems, especially those for understanding which students have to go beyond recalling/revising previously learned information. Students should be ready to reason and prove their ideas and positions, using information that goes far beyond covered in video fragment. Such assessment tasks should make students see global picture, however at the same time be focused on some of its aspects. Multiple perspective tasks that are usually covered in videos about new technologies, environment, social development, advanced industry are the best, requiring students to provide evidence or logical arguments in support of their judgments, choices or assertions.

Due to the purposes of the article which aimed to look into background of critical thinking and its various aspects; analyze the conditions of teaching critical thinking; produce an analysis of video materials available for teaching critical thinking; give variants of applying video materials into students' learning the following conclusions can be made.

The background of critical thinking and its various aspects are briefly covered, with reference to ancient philosophers and educators, who took great interest in development one's thinking skills and processing information, analyzing data etc. The historical chronicles explain the initial conditions of formation critical thinking theory, giving examples of educational reforms involved into processes of establishing and formulating the concept and basis of the critical thinking. 
Teaching critical thinking depends on conditions teachers and students are put into, the most important condition being the possibility to speak what a person thinks, be free and not restricted by someone's rules or ideas.

Video materials are considered to be rich and beneficial material for teaching critical thinking. They are used for teaching various courses, disciplines or themes, but usually are taken just as means of demonstrating some process or phenomenon. However, in the age of digital information video materials should be applied at every stage of teaching notwithstanding the subject or topic. There is variety of video materials on the open source sites that allows choosing any video fragment due to teacher's and curriculum's requirements. It is advised that video materials were not too long (not more than 10 minutes), with rational balance of graphical and sound information, it is better when materials are somewhat entertaining and enquiring, arising some problem or discussion, not just description.

As previously mentioned, video materials can be used for many kinds of tasks. Teachers should use all the possible activities for stimulating critical thinking in groups of students. Among such activities are tasks taken from direct, aural, functional, lexical and communicative approaches, for example, predicting the video, analyzing the advantages and disadvantages of the process/object shown, copying the movements from video, giving estimation to the process shown and - give variants of applying video materials into students' learning.

Therefore we can conclude that teaching critical thinking skills, or rather focusing students on applying these skills to the tasks they receive and for covering the topics they get becomes more productive by introducing video materials into educational process. We think the same can be used for various disciplines, as video materials are in open access and they cover all topics needed. The questions is that most of them are in English language, especially scientific language, and thus it is often difficult to understand the narrator or characters talking in the video. But great as we have already mentioned demonstrability is a great plus, acting as motivation factor for students and producing various tasks and problems discussion.

\section{ЛIТЕРАТУРА}

1. Brantlinger A. Discussing Discussion: A Video Club in the Service of Math Teachers National Board Preparation [Abstract] / A. Brantlinger, M. G. Sherin, K.A. Linsenmeier // Teachers and Teaching: Theory and Practice. - 2011. - 17(1). P. 5-33.

2. Conceptualizing critical thinking. Journal of Curriculum Studies /S. Bailin, R. Case, J. R. Coombs, L.B. Daniel // Journal of Curriculum Studies. 1999. - 31(3). - P. 285-302.

3. Donkor F. The comparative instructional effectiveness of print-based and video-based instructional materials for teaching practical skills at a distance. [Електронний ресурс] / F. Donkor // International Review of Research in Open and Distance Learning. - 2010. - 11(1). - P. 96-116. - Режим доступу: http://www.irrodl.org/index.php/irrodl/article/view/792/1486

4. Hager P. Critical Thinking in Teacher Education: A Process-Oriented Research Agenda [Електронний pecypc] / P. Hager, M. Kaye // Australian Journal 
of Teacher Education. - 1992. - 17(2). - Режим доступу: http://dx.doi.org/10.14221/ajte.1992v17n2.4

5. Lai E.R. Critical Thinking: A Literature Review. [Електронний ресурс] / Lai E.R. - 2011. - Режим доступу: http://www.pearsonassessments. com/hai/images/tmrs/CriticalThinkingReviewFINAL.pdf

6. McPeck John E. Critcal Thinking and Education / John E. McPeck // John Wiley, New York Teachers College Record. - 1983. - Volume 85, Number 1.- P. 154-157.

7. Mejia E. 102 very teachable films: A teacher's reference guide to using movies. / Mejia, E., Xiao, M.K., \& Kennedy, J./ Englewood Cliffs, NJ: Pearson ESL. 1994.

8. Sherin M.G. Teacher Learning in the Context of a Video Club (PDF). [Електронний pecypc] / M. G. Sherin, S. Y. Han // Teaching and Teacher Education. - 2004. - 20(2). - P. 163-183. - Режим доступу: http://professionalvision.org/pdfs/SherinHan_TATE.pdf

9. Stempleski S. (Eds.). Video in Second Language Teaching: Using, selecting and producing video for the classroom / S. Stempleski and P. Arcario. Alexandria, VA: TESOL, 1990. - 122 p.

10. Videobased Lesson Analysis: Effective Science PD for Teacher and Student Learning [Abstract]. / K. J. Roth, H. E. Garnier, C. Chen, M. Lemmens, K. Schwille, N. I. Z.Wickler // Journal of Research in Science Teaching, 48(2), 2011. - P. 117-148. [Електронний pecypc]. - Режим доступу: http://onlinelibrary.wiley.com/doi/10.1002/tea.20408/abstract

11. Барменкова О. И. Видеозанятия в системе обучения иностранной речи / О. И. Барменкова // Иностранные языки в школе: Научно-методический журнал. Министерство образования Российской федерации. Москва. - 1999. Вып. №3. - С. 20 - 25.

\section{REFERENCES}

1. Bailin, S., Case, R., Coombs, J. R., \& Daniels, L. B. (1999). Conceptualizing critical thinking. Journal of Curriculum Studies, Canada. 31(3), 285-302.

2. Brantlinger, A., Sherin, M.G., and Linsenmeier, K.A. (2011). Discussing Discussion: A Video Club in the Service of Math Teachers National Board Preparation [Abstract]. Teachers and Teaching: Theory and Practice, UK. Cambridge University Press. 17 (1), 5-33pp.

3. Donkor, F. (2010). The comparative instructional effectiveness of print-based and video-based instructional materials for teaching practical skills at a distance. International Review of Research in Open and Distance Learning, 11 (1), 96-116. Retrieved from: http://www.irrodl.org/index.php/irrodl/article/view/792/1486

4. Hager, P., \& Kaye, M. (1992). Critical Thinking in Teacher Education: A ProcessOriented Research Agenda. Australian Journal of Teacher Education, 17(2). Austria. Retrieved from: http://dx.doi.org/10.14221/ajte.1992v17n2.4

5. Lai, E.R. (2011) Critical Thinking: A Literature Review. UK. Pearson. Retrieved from: http://www.pearsonassessments.com/hai/images/tmrs/CriticalThinkingReviewFINAL.pdf

6. McPeck, John E. (1983). Critcal Thinking and Education. John Wiley, New York Teachers College Record, Volume 85 (1), 154-157.

7. Mejia, E., Xiao, M.K., \& Kennedy, J. (1994). 102 very teachable films: A teacher's reference guide to using movies. Englewood Cliffs, NJ: Pearson ESL. UK.

8. $\quad$ Roth, K.J., Garnier, H.E., Chen, C., Lemmens, M., Schwille, K., and Wickler, N.I.Z. (2011). Videobased Lesson Analysis: Effective Science PD for Teacher and Student Learning [Abstract]. Journal of Research in Science Teaching, 48(2), 117-148. Retrieved from: http://onlinelibrary.wiley.com/doi/10.1002/tea.20408/abstract 
9. Sherin, M.G., and Han, S.Y. (2004). Teacher Learning in the Context of a Video Club (PDF). Teaching and Teacher Education, 20(2), 163-183. Retrieved from: http://professionalvision.org/pdfs/SherinHan_TATE.pdf

10. Stempleski, S. and Arcario, P. (Eds.) (1990). Video in Second Language Teaching: Using, selecting and producing video for the classroom. Alexandria, VA: TESOL. UK.

11. Barmenkova, O.I. (1999) Video lessons in the foreign language teaching system. Scientific and methodical journal "Foreign languages in school", Iss.3., 20-25. [in Russian].

\section{Т.Л. Коршук. Розвиток критичного мислення студентів шляхом впровадження відеоматеріалів у навчальний процес. \\ Стаття розглядає питання використання відеоматеріалів для навчання критичного} мислення під час освітнього процесу, що відбувається у вищих навчальних закладах. Спершу даний аналіз попередніх досліджень, що стосуються критичного мислення та його особливостей, а також наведено інформацію про дослідників та їх основні ідеї щодо використання відео матеріалів у навчальному процесі. Детально проаналізоване поняття «критичне мислення» та його специфіка з точки зору необхідних якостей та вмінь людини для розвитку критичного мислення на високому рівні. Серед таких невід'ємних факторів $\epsilon$ відкритість до думок інших, неупередженість, гнучкість, чесність та готовність навчатись тощо. Стаття розкриває основні етапи розвитку думки при критичному мисленні, наголошуючи на тому, що при навчанні такого процесу необхідно звертати увагу на обов'язкову відсутність тиску з боку викладача, його відкритість та толерантність до будьяких ідей студентів. Далі представлені причини використання відеоматеріалів у навчальному процесі, із наголосом на те, що такий вид наочних матеріалів може і повинен бути використаний при навчанні будь-якої дисципліни. Наведені вимоги до відеоматеріалів, які включають тривалість та якість, інформативність та наочність, співвідношення тексту та зображення, наявність стимулюючого елементу у сюжеті тощо. У висновки винесені основні твердження статті про те, що використання відеоматеріалів може стати високопродуктивною i мотивуючою складовою навального процесу,тому необхідно розробити певну базу відеоматеріалів, яка у відкритому доступі повинна існувати для усіх вищих навчальних закладів країни.

Ключові слова: критичне мислення, креативні методи, відео матеріали, обробка інформації, мовна компетентність.

\section{Т.Л. Коршук. Развитие критического мышления студентов путем внедрения видеоматериалов в учебный процесс}

Статья рассматривает вопросы использования видеоматериалов для обучения критического мышления в образовательном процессе. Дан анализ предыдущих исследований о критическом мышлении и его особенностях, а также наведена информация о исследователях и их основных идеях по использованию видеоматериалов в учебном процессе. Подробно проанализировано понятие «критическое мышление» и его специфика с точки зрения необходимых качеств и умений человека для развития критического мышления на высоком уровне. Статья раскрывает основные этапы развития мысли при критическом мышлении, подчеркивая, что при обучении такого процесса необходимо обращать внимание на обязательное отсутствие давления со стороны преподавателя, его открытость и толерантность. Далее представлены причины использования видеоматериалов в учебном процессе. Приведенные требования к видеоматериалам, включающие продолжительность и качество, информативность и наглядность, соотношение текста и изображения, наличие стимулирующего элемента в сюжете. Выводы раскрывают основные утверждения статьи о том, что использование видеоматериалов может стать высокопроизводительной и мотивирующей составляющей стремительного процесса, поэтому необходимо разработать определенную базу видеоматериалов, которая должна существовать для всех высших учебных заведений страны в открытом доступе.

Ключевые слова: критическое мышление, креативные методы, видеоматериалы, обработка информации, языковая компетентность. 